\title{
A REGIONÁLIS FEJLŐDÉS ÚTJAI: GLOBÁLISTÓL A LOKÁLISIG
}

\author{
(Ways of Regional Development: from Globality to Locality)
}

\section{GEORGES BENKO}

A térgazdaság fogalmi keretei között a lokális a regionálisnak míg a globális a nemzetközinek feleltethető meg. A lokális-globális fogalompár nemcsak, mint a tudományos vizsgálódás tárgyára vonatkozó ellentétpár jelenik meg, hanem módszertani ellentéteket is felvet.

A „helyi környezetre" (régióra vagy vidékre) egy sajătos természeti, társadalmi, intézményi atmoszféra, vagy más szóval, a „regionális önállóság” jellemző. A helyi önállóságon alapulnak a többi régióval fennálló - többé-kevésbé előnyös kapcsolatok. A más térségekhez való viszonyulás alapját képezó ősszehasonlítás a tér belső struktúráját veszi elsősorban célba. Ezt a megközelítést nem nevezhetjük "globálisan" strukturalistának.

Éppen ellenkezőleg, a globális megközelítés a legtágabb struktúrában elfoglalt pozíciói alapján határozza meg a régiókat: eszerint a régió (és jellemzói) a regionális kölcsönhatások (interregionalisme) terméke. Ez a megkőzelítés magyarázza például a "centrum-periféria" viszonylatokat.

Ez a módszertani konfliktus nemrégiben új fordulatot vett: vita kerekedett a régiók közötti (azaz a nemzetközi) munkamegosztás és az endogén fejlödés fogalmairól, és ennek egyik jellegzetes formájáról, az ipari körzetról. Erröl a vitáól szól ez a tanulmány. A vita korántsem csak elméleti jellegü, hiszen a világ - és ezzel együtt szemléletünk is - változik, mi pedig újabb és újabb, a valóságban bekővetkezett változásokat magyarázni próbáló tipológiákat állítunk fel.

A tanulmány első és a második része a háború előtti és utáni, „ortodox” elméleteket - a városhierarchia elméleteit, a strukturalista elméleteket, ill. a „fejlödési stratégia” és a „függőségi elmélet” párharcát - veszi górcső alá. A harmadik rész bemutatja az „endogén” elmélet megújulását, a negyedik pedig a vita legutóbbi eredményeit ismerteti. A felsorolt elemek hordozzák a lokális és globális fogalompár dialektikáját.

\section{Az elsõ ortodoxia: a városhierarchia}

A térgazdaság (a regionális, vagy városgazdaság) első teoretikusai, a Jénai Iskola megalapítói (Christaller 1933, Lösch, 1940) a következő kérdést vetették fel: homogén térben (például, egy mező- és rétgazdálkodási célokra hasznosított vidéken) miként alakulnak ki az ipari vagy a tercier tevékenységgel jellemezhetö városi koncentrációk? Hogyan jön létre a hierarchia (a méretet, a szolgáltatások skáláját, azaz a jólétet figyelembe véve) az egyes agglomerációk között? 
A válasz egyszerünek tünik: a mikroökonómia elmélete szerint ez a folyamat a gazdaság profit-maximalizáló, kőltség-minimalizáló természetéből következik. Minden (ipari) termék és szolgáltatás elöállítása meghatározott szinten válik optimálissá (méretgazdaságosság). Ennek az optimumnak egy, a homogén térben megjelenö kereslet feleltethetö meg. Ha a termelö egy téregységet lát el a homogén térben termékeivel, a szállítási költségek (az áruszállítási költségek és a beszállítók, illetve fogyasztók útiköltségei) minimálisak lesznek. A városi termelés „,központi helyek" hálózataiba kezd szerveződni és a - kedvezỏ esetben hatszögletü formákba rendeződỏ - hálózatok egységei alkotják a teret. Christaller szerint, minél ritkábbak, kủlönlegesebbek a szolgáltatások (illetve, minél nagyobb tömegủ termelésnél tapasztalhatunk méretgazdaságosságot), annál nagyobb méretủek a hatszögletủ hálózati téregységek. Ha feltételezzük, hogy a hálózatok többségének csomópontjában egy-egy város van, és gondolatban összekapcsoljuk a "csomópontok központjai" körül létrejött hálózatokat, akkor szabályosan rajzolódnak ki elöttünk azok a centrumok, melyek a másodrendủ városokat vonzzák.

Az optimalizáló „láthatatian kéznek" köszönhetően így alakult ki a városi hierarchia a metropolisz operájától a falvak egyszerú szatócs boltjáig. Ne intézzük el azonban egy kézlegyintéssel ezt az elméletet. Mind az észak-európai és az északamerikai tágas síkságokat, mind a Franciaországtól szent Oroszország nyugati részéig terjedő területeket vizsgálva (nem véletlen, hogy Jénában született meg ez az elmélet) többé-kevésbé nyomon követhetjük ezt a modellt. Az elmélet mindenképpen továbbgondolkodásra ösztönöz.

Mindenekelött látnunk kell, hogy strukturalista sémáról van szó, Egy „központi hely" mérete és tevékenységi köre a hierarchikus városi térben elfoglalt helyétöl függ. Egyes kisvárosok esetében, például, bizonyos nagyobb jedentöséggel bíró tevékenységek, szolgáltatások azért szegényesek, hiányosak, mert e tevékenységek "helyét" már egy nagyobb, a hierarchiában magasabban álló, város foglalta el. Végül is, nem épülhet minden városban opera, nagyáruház, vagy egyetem. Wallerstein (1974) és Braudel (1979) „világgazdasági” elméleti sémảja alapján magyarázni tudjuk ezt a jelenséget: egyes agglomerációk („központok”) „sikeréböll” szükségszerủen következik, hogy a másik oldalon létrejöjjenek a "központokhoz" kapcsolódó alacsonyabb rendủ perifériák. Az „alacsony rendủség”, persze, viszonylagos fogalom: a legkisebb városi hely is mindig egy periféria középpontja egy sokkal finomabb szerkezetủ hálózatban természetesen.

De hogyan foghatjuk meg azt a bizonyos „láthatatlan kezet", amely az értékesebb tevékenységeket végül is egyes metropoliszokba tömöríti? Elsö pillantásra azt mondhatjuk, hogy mindez a verseny játékszabályaiból és az optimalizálás individualista jellegéből természetesen következik. A vállalatok úgy foglalják el helyüket a térben, hogy versenytársaiktól minél messzebbre, klienseikhez pedig minél közelebb kerüljenek.

Ez azonban így nem igaz. Elöször is köztudott, hogy minden központban sok, egymással versenyben álió és ugyanazt a szolgáltatást nyújtó vállalatot találunk. Ezt a jelenséget akár ugyanabban az utcában is megfigyelhetjük (gondoljunk például a konfekció árut forgalmazó üzletek szük utcácskáira Párizs belvárosában). Ez a „tőzsde”, a „piac” (piac a szó eredeti értelmében, gondoljunk például egy „állatvásárra”) hatása: oda kell települni, ahol a vevők az egyes szolgáltatásokat, 
vagy árukat keresik, és a közismert helyen gyülnek össze azok, akik ugyanazt a szolgáltatást, vagy árut kínálják. Nem egy vállalat, hanem a vállalatok agglomerációja foglal el és lát el egy téregységet. Ezzel máris elérkeztünk a „,körzet” (district) fogalmához! Amikor azonban vizsgálódásunk során hálózatonként csak egy-egy termelési és szolgáltatási egységgel találkozunk, joggal feltételezhetjük, hogy nem a verseny, hanem egy szervezet tervszerü telepítésének következménye a ,hely” elfoglalása. Az egyház a plébániákat és püspökségeket a falvakba és városokba helyezte el (és nagyon gyakran ez vonzotta oda a városi armatúrát); az állam elemi iskolákat, középiskolákat, egyetemeket, kórházakat telepített le. Ezzel, annak érdekében, hogy szolgáltatásokkal lásson el egy területet, tudatosan megszilárdította a városi hierarchiát...

Egyes általános egyensúlyi elméletet valló teoretikusok Hotelling (1929) játékelméletének paradoxonát használták fel a verseny ellenére létrejövő agglomerálódási hatás bizonyítására. A fürdőváros strandján múkődó két fagylaltárusnak az lett volna az érdeke, hogy felosszák egymás közt a strandot, oly módon, hogy az egyik árus a strand első negyedébe, a másik a strand harmadik negyedébe helyezi el fagylaltos bódéját. De mivel szerettek volna egy kicsit „lecsípni" a másik területéból, mindketten a strand közepén telepedtek le, így viszont elveszítették a strand szélein napozó vevőiket!

Nem valami meggyőző azonban ez - a nem-kooperatív játékra alapuló magyarázat; hiszen azért telepszik le a két árus a strand közepén, mert a vevők tudják, hogy ott vannak a fagylaltárusok (nem beszélve a napozókrém, a napszemüveg, stb. árusairól). Az agglomerálódás nem egy mindent elsöprő perverz hatás. Söt, ellenkezőleg, a versenytársakra mindez pozitív hatást gyakorol, és megfigyelhetjưk az agglomerálódás hatását: az ágazaton belül jelentkezik az agglomerálódás gazdaságossága (a fagylaltot készítésének helye mellett árusítják), míg az ágazaton túl a közelség hatása érvényesuil (napozókrémet is vásárolnak, miközben már nyalogatják a kezủkben lévő fagylaltot).

Ez, az agglomerálódásból magából következő, az ágazat szempontjából azonban külső hatás a Jénai Iskola által kidolgozott elmélet másik hiảnyosságára is felhívja a figyelmet. Miért kell kiindulni abból, hogy a hálózatok csomópontjában metropoliszokat találunk? Mert, vallják a „külső hatások” teoretikusai, nemcsak az elszigetelhetỏ piaci tranzakciók érvényesủlnek: a "nagyság mámora", a verseny, az informális csere, az árakban ki nem fejezett kölcsönösség hatása mind az agglomerálódás irányába mutat - és íme, újra szembetalálkozunk az atmoszféra elméletével (mint például, Marshallnál, majd 70 év múlva Becattininél).

Így, a legstrukturalistábbnak nevezhető, a legfunkcionalistább területi közigazgatási dőntéseket ihlető térelmélet instabil, és mennyiségi ismérvekkel ki nem fejezhetö alapokon nyugszik, egy olyan - az agglomerálódásra jellemző - nem piaci szervezỏdési elven, amelyre legfeljebb a felsőszintủ közigazgatási döntések vannak ösztönzỏ hatással. Összefoglalva: bizonyos városok sikeresebbek másoknál, mert „megérdemlik” ezt a sikert. Ezekben a városokban a gazdasági és (kulturális) élet aktívabb, a lakosság egyuittmúkỏdési készsége fejlettebb. A térbeli hierarchia tehát okozat, és nem ok: minden város fejlödhetne, ha hasonló tulajdonságokkal rendelkezne. 
Ha úgy fogjuk fel a várost (és az azt körülvevő régiót, amely hozzájárul a város fejlödéséhez) mint közösségi tárgyat, - akkor, mintha csak Möbius szalagján haladnánk elöre - hirtelen, az összes társadalomtudományra jellemzö "kettősség" (az egymással szemben álló elméletek, társadalomtudományi megközelítések egyidejü jelenléte) tárul fel elöttünk: a holizmus és az individualizmus, a struktúra és a fejlödési pálya, azaz, a téranalízis nyelvére lefordítva, a „globális” és „lokális”. E két pólus között ütközik a 60-as évek két nagy térbeli ,ortodox elmélete”.

\section{Lemaradás vagy függöség?}

\section{A háború utáni ortodoxiák}

A központi helyek hierarchiáját magyarázó elméletnek legnagyobb gyengesége minden bizonnyal az, hogy a rendszert homogén térbe helyezik el. Homogén térben valóban feltételezhető a városi hierarchia strukturálódása (a piacnak, a külső hatásoknak, vagy a közigazgatási döntéseknek tulajdoníthatóan). A probléma azonban az, hogy a régiók, országok, egymáshoz hasonlítva, nem homogén térségek. Normandiában, Hessenben, vagy Mazúriában valóban kialakultak az egymáshoz struktúrájukban hasonló Christaller-féle hierarchizált városhálózatok, ugyanakkor, mivel ezek térsége - egymáshoz hasonlítva - igen heterogén, a hálózatban található városok társadalmi összetétele, gazdagsága nagy mértékü különbséget mutat. Az egyik fejlettebb, a másik kevésbé fejlett, és bár Párizsban és Saõ Paulóban is vannak ipari területek, lakónegyedek, gazdag és szegény városrészek, Párizs nem Saõ Paulo.

Az 1960-as, 1970-es években régiók, országok és a területükön található városok egyenlőtlen fejlödését magyarázó elméletek jelennek meg két, egymással szemben álló ortodoxiában. Eleinte a gazdasági tevékenységek térbeli fejlödésével kapcsolatos elméletet fogadják el. Eszerint, Colin Clark (1951) történelmi sémája alapján, minden földrajzi térségnek (régiónak, országnak) át kell mennie valamennyi fejlődési szakaszon: a pre-indusztriális (primer), az indusztriális (szekunder), és a poszt-indusztriális (tercier vagy kvaterner) idöszakokon. Az országok azonban különbőző idópontokban állnak a rajthoz, és ebből fakad, hogy a történelem adott pillanataiban egyes országok relatíve elmaradottabbak más országokhoz képest. Ezen alapszik W. Rostow (1963) fejlódési fokozatainak elmélete. A földrajzi terek fáziskülönbségei mentén legfejlettebb zónákban kifejlesztett új termékek - a termékciklus végén - elértéktelenednek, és az "újủonságok" termelése áthelyeződik a fejletlenebb régiókba (Vernon 1966, termék-ciklus elmélete).

A Clark-Rostow-Vernon féle modell a nagyobb léptékekkel mérö elméletek osztályozása alapján nem tekinthetö "globálisan strukturalista" modellnek. E szerint nincs semmi akadálya annak, hogy az utolsó, kvaterner szakaszban, valamennyi ország fejlődési pályája hasonló belső struktúra felé konvergáljon. Az egyes országok relatív „lemaradása" nem feltétlenül strukturális okokra vezethetö vissza: a történelem véletleneinek tulajdonitható, hogy belső strukturális okok miatt egyes országok előbb álltak a rajthoz mint mások. 
A genealógiai megközelítéssel dolgozó és az országok „perszonalitását” kutató elméletek a Weber-i vállalkozói erkölcsre, az első ipari forradalom során nélkủlözhetetlenné váló nyersanyagokra, és a feudalizmus hanyatlására (amely lehetövé tette, hogy a burzsoázia megjelenjen a történelem színpadán) szoktak hivatkozni akkor, amikor egy ország „fejlettségêt” vagy „perszonalitását” próbálják magyarázni. Ebből következik, hogy egyes országok „lemaradása” belsö okokkal magyarázható: az éghajlat okozta problémákkal, sajátos társadalmi struktúrákkal, konzervatív ideológiákkal stb. Egy-egy ország kiválása, kiemelkedése belső reformok következménye is lehet. Ez a felemelkedés pozitív hatást gyakorolhat más országok fejlödésére: az utolsók - felhasználva mások megszerzett tudását és ismereteit - „beérhetik" az elsöket... Ebben az értelemben ez az ortodoxia az „individualista” metodológián alapul (a „kollektív egyének” az országoknak feleltethetök meg).

Ezzel az ortodoxiával áll szemben egy globális strukturalista megközelítés, a függőség elmélete és ennek különbözö változatai. Ez az elmélet azt sugallja, hogy egyes' országok elmaradottsága és mások fejlettsége ugyanazon okokra vezethetó vissza, azaz, ez utóbbiak gazdagsága az elmaradottak nyomorából táplálkozik. Valamikor még lehetséges volt saját erőre támaszkodva eljutni az ipari kapitalizmus szakaszába, de a politikai uralmi viszonyok, majd a világpiaci verseny tartósan elzárta az utat az újonnan jöttek elöl. Így alakult ki és erősödőtt meg a nemzetközi munkamegosztás az uralkodó - ipari és tercier jellegü - gazdasági központok és az általuk uralt - mezőgazdasági termékeket és nyersanyagokat exportáló - periféria között. Az egyenlötlen csere lehetetlenné tette, hogy a periférián a kiemelkedéshez szükséges eszközök felhalmozódjanak, míg a centrum egyre növekedö versenyképessége egyre magasabbra emelte a „lécet” az újonnan jövő versenyzők elött.

A második megközelítés regionális szintủ alkalmazásával megmagyarázhatóvá vált a francia, brit, vagy az észak-amerikai régiók egyenlötlen fejlödése. Az 1960-as évek végétől azonban nem lehetett figyelmen kívül hagyni azt a tényt, hogy egyes periférikus területek iparosodni kezdtek. Magyarázhatjuk-e ezt a jelenséget Rostow és Vernon paradigmájával, amely szerint ezek az országok az elértéktelenedett ipari termelésre alapozva próbálnak meg kiemelkedni és fejlödni? A tényeket nem lehet kétségbe vonni, ám ezek a folyamatok nem vezetnek szükségszerüen az országok felzárkózásához, a tér homogénné válásához. Valójában mindig elfogadott volt az a vélemény, hogy az ipari társadalmakon belul, a régiók között az egyenlötlenség minöségi szintjei alakultak ki, ezt azonban inkább egyidejũ komplementaritásnak tekintették, mint időben eltolódott hasonlóságnak. Ami a francia régiók közötti munkamegosztást illeti, a háború elótti mezőgazdaság/ipar komplementaritás helyébe, új régióközi munkamegosztás lépett. Az új régióközi munkamegosztásra jellemző, hogy ugyanabban a termelési ágban a termelö tevékenység három funkciója jelenik meg egy időben: az ötlet, a minőségi termelés és a rutinszerú termelés, összeszerelés. Ezt a hármas beosztást, a fordista termelési modellt tekintették a „tudományos” munkaszervezés végső formájának, és térbeli megjelenését ágazati körforgásnak nevezték el. 
Ez a tézis gyorsan nagy népszerüségre tett szert, és az 1970-es évek végén a harmadik világ iparosodó országainak megjelenésével, egy „új ortodoxia" kialakulásához vezetett: az új nemzetközi munkamegosztás elméletéhez (Fröbel, Heinrichs, Kreyes 1980). A fejlett országok (vagy régiók) egyrészt a gazdasági irányítás és a fö piacok központi régióivá váltak, másrészt a élómunkát igénylő - és végső soron saját piacaikra irányuló - termelést „térben áthelyezték” a sokkal szegényebb és kevésbé képzett munkaerővel rendelkező régiókba.

A világgazdaságot uraló, az ipari munkamegosztást is magába foglaló „globális strukturalizmus" kissé korai általánosítása nyomban ellenállást váltott ki a teoretikusok söt még a "régióközi új munkamegosztás" hívei között is (Aydalot 1984, Lipietz 1985, 1986, 1990b, Massey 1984). Kétségtelen, hogy a Franciaországhoz hasonló, politikailag homogén területeken a vállalatok képesek kiterjeszteni térkapcsolataikat az egyenlötlenül fejlett régiókra, és a termelö üzemeket, illetve az alvállalkozások kapcsolati rendszerét áthelyezik az „elmaradott” régiókba. Nemzetközi szinten (ahol ezt a strukturáló szerepet a multinacionális cégeken belül oldják meg) az ilyen sémában nem veszik figyelembe a helyi társadalom autonómiáját, az érintett állam szerepét, a helyi társadalmi viszonyok és kapcsolatok természetét, az érintett állam által ellenörzött szabályozási rendszert stb.

A reguláció módszerének fejlődése Franciaországban ezen - az állam által intézményesitett kompromisszumok jelentöségére és a kompromisszumokkal ösztönzött "felhalmozási rendszerre" is felhívta a figyelmet. Ha a nemzetközi vállalatok ki akarják terjeszteni ágazati pályáikat más országokban (mint ahogy erre korábban regionális szinten sor került), akkor egy sokkal önállóbb szervezettel, az érintett állammal és annak intézményeivel találják szemben magukat.

A valóságban a „globális/lokális” kettősség az ágazati pályák elméletével együtt jelent meg. Doreen Massey így irt erről (1978): „Lipietznél (1977) a régiók hol saját maguk - genealógiájuk- által, hol a régióközi munkamegosztásban együttesen elfoglalt helyük által meghatározottan jelentek meg". Ebben az idöben kritikaként fogalmazódott meg, hogy a régiók csak a globálisabb struktúráktól fokozatosan átvett jellemvonásokat viselhetik. Néhány évvel késóbb ugyancsak az angolszász radikális földrajzi irányzat vezette $D$. Masseyt (1985) az új felismeréshez: ,the unique is back on the agenda". Vissza kell térni az egyeshez, a különöshöz, Vidal de la Blache „regionális egyeđiségéhez”. Így az üj nemzetközi munkamegosztás ortodoxiájának regulációs kritikája megdöntötte a globális strukturalizmust, oly módon, hogy a helyi területi „egyediséget” helyezte az állam-nemzet viszonyának középpontjába. Mások még ennél is messzebbre jutottak.

$$
\text { Az „endogén" regionális fejlödés }
$$

$\mathrm{Az}$ 1980-as évek végén megjelenő tanulmányok már egyre gyakrabban foglalkoznak azzal a gondolattal, miszerint szakítani kell a globális strukturalizmussal, valamint a Rostow-féle fejlödési szakaszok predeterminista elméletével. Ezek az elméletek már egy új ortodoxia felé mutatnak, miszerint az ipari régiók sikerét és növekedését belső dinamizmusukta kell visszavezetni. 
A kiindulási pont alapjait vitathatatlanul A. Bagnasconak, C. Trigiliának (1977, 1984, 1988), és S. Brusconak $(1982,1984)$ a „Harmadik Itáliáról” szóló munkáiban találhatjuk meg. A Milánó-Torino-Genova klasszikus ipari háromszőg és a reménytelenül elmaradott Mezzogiorno között olyan sajátos iparral rendelkezö városok, vidékek emelkedtek ki, melyek önerejükböl lettek sikeresek a világpiacon. Míg az előbb említett tanulmányok inkább az endogén fejlödésủ régiók társadalmi jellemzőivel foglalkoztak („a piac társadalmi építése”), G. Becattini (1979) arra hívta fel a figyelmet, hogy e régiók tipikus, a kis- és középvállalatok rendszerének keretei között, a verseny, a vetélkedés és a kooperáció sajátos keverékét magába foglaló ipari szervezettel rendelkeznek. Mindez eszünkbe juttatja $A$. Marshallnak 1900-ban megfogalmazott elméletét: az ipari körzetet (district industriel). E szerint kétféle ipari szervezet létezik: az egyik az egyetlen nagyvállalati keretbe integrálódó munkamegosztás által irányított szervezet, míg a másik a termelőfolyamat egy-egy szegmensére specializálódó kisebb cégek között létrejövő dezintegrált társadalmi munkamegosztás (a piaci folyamatokon és a kölcsönkapcsolatokon keresztül csatornázódó) koordinációján alapul.

Zseniális elméletükben $M$. Piore és C. Sabel (1984) az ipari körzetek sikereit azoknak az általánosabb folyamatok speciális eseteiként betöltött szerepével magyarázták. A regulációs elméletre hivatkozva azt állították, hogy a mereven strukturált fordista tömegtermelést a rugalmas specializáción alapuló rendszer követi (amely térszerkezeti átalakulást is eredményez), és a fordista ágazati kapcsolatokat felváltják a körzetek. Az új ipari térszerkezetben a munkaerő szakképzettségén, a decentralizált innováción és a vállalatok közötti piaci és kölcsönkapcsolatok által létrejövő koordináción van a hangsúly. E két jellemzỏ már utal az ipari körzet atmoszférájára.

Ezzel párhuzamosan, A. Scott, M. Storper és R. Walker, kaliforniai geográfusok gondolkodására államuk és különösen Los Angeles növekedése, fejlődése gyakorolt igen nagy hatást. Különbözö kiindulási pontból hasonló következtetésig jutottak. Először is, érdeklődésük középpontjában a metropoliszok álltak, elsősorban a megapoliszok, amelyekben utólag felismerték a körzeteket, mint a megapoliszokat „patchwork”-ként alkotó részeket. Ámbảr ismerték a regulációs elméletet, melybỏl saját terminológiájuk egy részét is merítették, elsősorban a munkamegosztás dinamikájának és az agglomerálódás külső hatásainak neomarxista, illetve neoklasszikus (Coase 1937, Williamson 1975) elemzéseire támaszkodtak. A. Scott a Metropolis címü szintézisében (1988) rámutatott, hogy a kaliforniai Orange megye elektronikus ipari körzetének kezdetben nem volt kvalifikált munkaeró-piaca (szemben a Szilícium völggyel, ahol a Stanford Egyetem ipari parkja fejlödött ki). Storper és Walker (1989) a majdnem a semmiből kifejlödö pólusok megjelenésének modelljéröl értekeztek, kvázi-nietzschei tónusban.

Így a kis olasz körzetektől a világméretü megapoliszokig a ,rugalmas specializáció" új technológiai paradigmája nemcsak az üzemek és irodák városi letelepedésének újra éledő folyamatát magyarázta, hanem a metropoliszok mennyiségi növekedésének új korszakára is felhívta a figyelmet: íme, megtalálták a fordizmus válságából való kilábalás új térbeli formáját. A világ városi régióinak és városainak jövöbeli hierarchiáját a körzetek (vagy a körzetek csoportjainak) sajátos, belsö stratégiája fogja meghatározni: győzzcnek a legjobbak! 


\section{A vita}

Levonhatók-e egyértelmü következtetések az új gazdasági terek földrajzával kapcsolatos, majd 15 éven át tartó vitákból, kutatásokból? Nem lehetünk ebben biztosak. Bőven találunk viszont új gondolatokat, módszereket. Világméretủ társadalmi-gazdasági válság és a válság által generált térbeli (városi és regionális) feszültségek szenvedö alanyai voltunk és vagyunk. Ez a válság fájdalmas következményekkel jár, és ez a fájdalom néha a kutatók visszafogott, hideg elemzéseiben is visszaköszön. Senki sem lehet közömbös az újonnan születő világgal szemben: ez más, mint amilyen gyermekkorunkban volt, és más, mint ahogy azt idösebb kollégáink régebben leírták. Felfedezni egy új - a jővő társadalom elsó jeleit, nos, ez a kutató legnemesebb törekvése, mesterségének öröme és kockázata. A jövöre vonatkozó elképzelések a jelenlegi kutatások eredményeiből, következtetéseiből alakulnak ki. Ezek az elképzelések, jóslatok szerteágazóak, nagymértékben különböznek egymástól, és ez így is van rendjén. A kőzös vonásokból azonban lassan mégis kirajzolódik elöttünk a kép: egy új paradigma.

Ez mindenekelött a választott módszerben jelenik meg. Visszatért az, ,ipari szervezet": a városok elemzésének középpontjában az elkủlönült gazdasági tevékenységek kőzötti kapcsolatok vizsgálata áll. Húsz évvel ezelőtt született meg az ésszerú tervezés fantazmagórikus elmélete, vagyis a termelést, a társadalmi újratermelést és a teret strukturáló nagyvállalati és állami tervezés gondolata. Úgy tưnt, a városi és regionális tervezési folyamatokat a hierarchia (a vállalaton belül) és a kormányzati gyakorlat (a társadalomban) uralja. Manapság viszont, a szereplök versenyhelyzetben hozott döntéseit nyilvánvalóan és elsösorban a spontaneitás vezérli. Ez az alapvetó fordulat lehet az új városi gazdaság kulcsa is - korunk kulcsszavai a „vertikális dezintegráció”, és a „társadalmi munkamegosztás”.

Minthogy azonban a társadalom mégiscsak egy egészet alkot, szükség van arra, hogy valamilyen módon szabályozzák ezeket az egymástól elkülönülö jelenségeket (a vállalkozói szubjektivitás és a társadalmi koherencia közötti ellentmondást) még a válság idején is, de kủlönősen a válságból való kilábalás folyamán. Az első szembetủnő eredmény a tevékenységek materializálódása a térben, a gazdasági vidék - a fogalom eredeti értelmében - tartamilag a reguláció egyik legelsỏ formájává vált, még a piac, a termelö és ügyfele, ill. a munkaadó és munkavállaló közötti elsö monetáris tranzakciót megelözően. Mint ahogy a XIX. században, ahol is az „egyszerü kooperáciô", az egy mühelyben dolgozó kézmüvesek csoportja jelentette a tỏkés hierarchia elsó állomását (a Foucault-nak oly kedves „panoptikum” első változata), a potenciális elönyökkel és alacsony árakkal járó agglomerálódást. Ez volt és maradt a tôkés piac első feltétele.

Amikor alacsony árakról beszélünk, elsősorban nem is a szállitás költségeire gondolunk, hanem sokkal inkább az információ, a „tranzakció" költségeire. Amikor információról beszélünk, akkor nem a hirdetöoszlopon megjelenö újságokra, vagy a publikált árjegyzékekre gondolunk; a szó eredeti értelmében használjuk a kifejezést: az újról, a létezésre alkalmasról, a valószínütlenröl van szó, amely a megszokott alapzajból emelkedik ki. E tanulmányok másik eredménye éppen itt ragadható meg: a telematikának ugyanis nincs szüksége az agglomerálódásra. Az urbanisták mégis 
az „információ technológiájáról” beszélnek, de ahhoz, hogy megértsük ennek a „müvészetnek” (techné) általános törvényszerüségét, ott kell lennünk, éppen azon a helyen, és a szemünk elött kell az eseményeknek lezajlaniuk.

Az agglomerálódás, a térben lejátszódó hosszú időn át tartó tanulást, a megismerés folyamatát jelenti tehát. Marshall nyomán gyakran hivatkoznak a kutatók az „atmoszférára”, amely a „kultúra, az „oktatás”, a „gyakorlat” megfelelöje. Ez a kreatív gyakorlat kollektív formája, ez az, aminek segítségével az emberek közlik egyéni élményeikből fakadó tapasztalataikat, ez az egyéni szubjektivitás kollektív alapja.

Természetes tehát, hogy amikor a válság megingatja a nemzetállamok makrogazdaság feletti uralmát, amikor az ủj technológiák felbukkanása és a piaci instabilitás elbizonytalanítja a nagyvállalatok megszokott irányítási módszereit, egyszóval, amikor visszafejlődik a „hierarchia”, új eröre kap az agglomerálódás, mint a piac „előszobája”, mint a piaci verseny küzdőpályája. Jelenleg és a közeljö vőben az urbanizáció látszik „,befutónak”.

Vajon az ipari agglomerálódás, - az ipari körzet - csak a ,piacon" müködik? És vajon a piac a hierarchiák (az oligopóliumok és a politikai társadalom) erejének átmeneti gyengülése vagy a fejlỏdés új modellje (amelyet a technológiai forradalom indukált), a rugalmas felhalmozás elterjedése következtében erősỏdik-e meg? Erröl szól a vita.

Egy alapvető hiátus osztja meg - az olasz Becattini, Brusco, Bagnasco, Sforzi, Trigilia és Garofoli által képviselt - a körzet hivớket (les aficianados). A „Harmadik Itália csodájának" körzetei (az 1960-as évektöl az 1980-as évekig) nem tisztán gazdasági körzetek, de nem is egyszerüen kollektív javak, amelyek elönyben részesítik a kereskedelmi tranzakciókat. Itt az „atmoszféra” jelenik meg a szabályozás más módjaiban: a civil társadalom keretei között a családban; a vállalkozók és alkalmazottak közötti bizalomban, a helyi közösségek szerepében stb. A (szükségszerüen elég kisméretü) „közösség” fogalmát Tönnies értelmezésében (Gemeinschaft) használják, és nem az individualista kereskedő társadalom (Gesellschaft) értelmében.

A spektrum másik végén a kaliforniai $A$. Scott áll ${ }^{2}(1988,1993)$, aki müveiben tiszta kőzgazdasági logikával mutatja be „a töke és a munka gigantikus felhalmozódását" az 1980-as évek megapoliszának, Los Angelesnek, látványos fejlödésében. Az „amerikai álom” egyenes folytatásaként (nem feledkezve meg a többiekról sem) magasztalja a vállalkozó szellem bölcs géniuszát, a decentralizált teremtő képességet, és e tényező vonzó és integráló erejének érvényesülését a világ olyan részeiben is, ahol ennek nem volt múltja, nincsenek gyökerei... Nem hagyja figyelmen kíviul a reguláció nem-piaci formáit az agglomerálódáson belül, de egyértelmüen hangsúlyozza, hogy mindezek mellékes szempontok Los Angeles esetében... És amikor az olaszok csak óvatosan mernek következtetni a körzetekre nehezedő veszélyekre, $A$. Scott magabiztosan hirdeti a fejlöđés új modelljének, a "rugalmas felhalmozásnak" érvényességét, és felvázolja annak körvonalait: a polarizálódást a munkában, a társadalomban, a piac győzelmét, az állam visszahúzódását, a technika és a munkaerő rugalmasságát. 
A vita más résztvevői (többek között $A$. Amin, F. Martinelli, E. Schoenberger) szerint a körzet új formája nem mutatja meg egyszersmind a válságból való kivezető utat is. Ezt három okkal magyarázzák. Elöször is, a régi fordista forma még nem múlt ki: a nagyvállalat és intézményeinek hierarchikus hálózata, a leányvállalatok és alvállalkozók, a menedzseri tervezés egyáltalán nem láthatatlan keze mindenütt nyomot hagy a térben. Másodszor, az olasz körzetek sajátos eseteket képviselnek; alapvetően a világgazdaság és egyéb függöségi viszonyok által meghatározottak, és ezt jobbára figyelmen kívül hagyják. Az olasz termékeknek tulajdonított minőség nem fejezi ki annak társadalmi költségeit: a kizsákmányolt nők munkáját, stb. A minősítés nem a legfontosabb jellegzetessége az új modellnek. Harmadsorban, még ha el is fogadjuk a rugalmas felhalmozás új modelljének hipotézisét, e modellnek különbözö formái létezhetnek, és a régi hierarchia (a fordista multinacionális vállalatok jellegzetessége) megerősödve még visszatérhet az alvállalkozói piaci kapcsolatokon keresztül. Lehet, hogy a kisvállalkozók függetlensége az 1970-es és 1980-as években a bekövetkező újrarendeződés rövid állomása - mintegy „zajos rendcsinálás" - volt csak a tökekoncentrálódás évszázados folyamatában. De még egyértelmübbek lehetünk, és visszatérhetünk a probléma forrásához: a fejlödés új modellje talán még nem is létezik, hiábavaló tehát a térbeli fejlödés formáit a „rugalmas felhalmozás” Prokrusztész -ágyában keresni. Sokkal érdemesebb lenne a szabályozás új formáit - és annak koherenciáját - a gyakorlatban (in vivo) tanulmányozni.

Ez a kérdés új gondolatokat szült az 1980-as, '90-es évek fordulóján. És mivel ebben az esetben a városi régiókról van szó, a figyelem középpontjában a városi agglomerálódás és az irányítás, a törvényhozás és az állam tevékenysége közötti közvetítỏ regulációs formák álltak. Létrejött tehát egy ủj fogalom, amelyre - minden próbálkozásunk ellenére - nem találunk megfelelö francia szót: ez a gouvernance ${ }^{3}$.

Ha tovább gondoljuk a dolgot nyilvánvalóvá válik, hogy a nem-piaci és nemállami regulációs formákról van szó. Gramsci meghatározásából kiindulva (az állam $=$ a civil társadalom + a politikai társadalom) a közösségi reguláció (gouvernance) $=$ a civil társadalom mínusz a piac... Söt, hozzátehetjük még a helyi politikai társadalmat, az önkormányzatokat is.

\section{Hálózatok és politikák}

A térbeli változás két következménnyel járt: egyrészt a hálózat fogalmát ezentúl a körzet (district) tölti be, másrészt a politikai erök szerepének vizsgálata újra fontos szerepet kap.

Beszéljünk először a hálózatról. A hálózat a piaci folyamatok hatókörén kívül létrejövő - vállalatok közötti - szervezödés egyik formája, melynek irányításáról már szóltunk. A vállalatok közötti viszonyokat ́́gy vagy a hierarchikus (függöségi) kapcsolatok, vagy a „partneri” kooperációs kapcsolatok határozzák meg. Storper, Harrison, Salais tanulmányaikban a technológia iránt (ez nem újdonság!) és ami még meglepöbb, a társadalmi munkamegosztás fejlettsége iránt is közömbös irányítási formák szélsőséges változatáról írnak. Léteznek olyan körzetek, amelyeket a körzetben található nagyvállalatok "központjai" strukturálnak, és paternalista körzetek, amelyeknek semmi közük sincs a marshall-i körzetekhez. Ettöl kezdve a vertikális dezintegráció földrajza azonosítani próbálta magát az elmúlt idök fordista 
fóldrajzával, amelyet hajdan $M$. Castells és F. Godard karikírozott a Monopoleville (1974) c. könyvben: ezek valójában olyan ipari zónák, amelyeket a szerény bérlakások és az alkalmazottak lakónegyedeinek nagy együttesei egészítenek ki. Korántsem csupán a múlt továbbéléséről van szó. Ennek egyik leglátványosabb példája Toyota-City, amely, ha valamire, akkor a poszt-fordista irányítási módszerre kiváló bizonyíték ( $B$. Coriat [1991] „Ohnizmusnak” nevezné ezt), amelyet just-intime szolgáltatások, minőségi körök stb. jellemeznek.

Másrészt a hálózat - amely inkább funkcionális értelemben használt, mint fóldrajzilag - hihetetlen módon kibövíti a megfigyelt új „objektumok" térbeli lehetőségeit. Amennyiben az új ipari szervezet lényege a gazdasági egységek irányítási önállóságának és azok egymás kőzötti rutin jellegü kooperációjának viszonya, a hálózat a szervezet technikai és társadalmi formáitól válik függóvé. Ezeknek egyrészt ,irányítottnak", másrészt koordináltnak kell maradniuk. Az agglomerálódás során létrejövő elönyök azonban nem fedik le az összes területet: ezeket a hiányosságokat jelenleg a jól kiépített közlekedési és telekommunikációs hálózatok kompenzálni tudják. A körzet szintjén túl (ami önmagában is már egy hálózat, sót egyes esetekben a körzetet egy téregység "fényudvarának" is nevezhetjük) kirajzolódik előttünk a „körzetek hálózata”. Ezt a jelenséget akkor tapasztaljuk, amikor az iparvállalat két városba telepủl.

Ennek jó példája a Párizsban és Toulouse-ban múködő repulögépgyártás. A toulouse-i repülögépgyártás régiója komoly állami múltra visszatekintő, az Aérospacial köré szerveződött légi és ürkutatáshoz kapcsolódó hierarchikus körzet (ez a szerkezet még a világháború előtti időkböl származik, amikor is a repülőgépgyártást hadiipari megfontolások is befolyásolták). Itt elsősorban a végtermék, tehát a repủlögépek összeszerelésével foglalkoznak. Ebben a megközelítésben a toulouse-i repülőgépipar egy európai méretü, ipari körzeteket magába foglaló hálózat részét alkotja (ez esetben a francia Airbus gyártásában). A SNECMA CFM-56 motorjait viszont egy másik csúcstechnológiájú körzetben gyártják, a párizsi agglomeráció délnyugati negyedében (,a SNECMA ív-ben”). Ez utóbbi a „klasszikus” ipari körzet romjain épült, vagy még inkább a francia szocialista mozgalmáról híres valamikori „Vörös Övezet” közelében (ahol HispanoSuiza már 1936-ban szervezett sztrájkokat a Bois-Colombes-ban).

Ez a terület, részben más körzetekkel, a párizsi "Tudományos Övezettel" (la Cité Scientifique) és az Hauts-de-Seine déli részén lévő elektronikai gépgyártás körzetével esik egybe, északon a Défense üzleti negyedével (Párizs melletti irodaközpont) határos. A párizsi repuilőgépgyártó körzetet partneri viszony köti össze az új-angliai General Electric telepuléshelyekkel is. Más körzetekhez is kapcsolódik a felsoroltakon kívủl, amelyek szintén kooperálnak Toulouse elektronikai iparával. A térség tehát nemcsak a „körzetek hálózatához” tartozik, hanem a ,hálózatok körzetéhez" is. A nyugati és a déli autópályák közötti területen, a Saclay-i fennsik irányában, Párizstól kb. $20 \mathrm{~km}$-re délre, (ahová egyébként nukleáris ipar települt) kủlönböző gazdasági ágazatok koncentrálódnak. Ezek az ágazatok gyakran tranzakciós kapcsolatban állnak egymással, mindenekelött ugyanarra a föleg jól képzett munkásokból, technikusokból, mérnökökböl és tudományos kutatókból álló munkaerőpiacra települtek. E térségben kialakult az ágazatok közötti agglomerálódás, és az urbanizáció érezhető előnyökkel jár. Ez az „atmoszféra” már nem azonos a - Carnénak és Prévertnek oly fontos - költói realizmus atmoszférájával, amely a régi Vörös Övezet romjain agonizált! Ha arra gondolunk, 
hogy Toulouse-ban nemcsak repülőgépgyártás folyik (hiszen ott van a l'ONIA, az elektronikai ipar...), láthatjuk, hogy milyen sajátossággal rendelkezik egy metropolisz: ez a ,hálózatok körzete”, a földrajzi közelséggel és föleg hasonló „társadalmi típus”-hoz tartozó ipari területek agglomerációja, amely már azelőtt létrejön, mielött közöttük bármiféle kereskedelmi tranzakció végbement volna.

Ily módon finomítják - Garofoli elméletét kibỏvítve - Leborgne és Lipietz (1991, 1992) gondolatai a "területi rendszer" fogalmát. Grenoble például egy "területi rendszer": az elektronikai ipar fejlödése nemcsak belső okokra vezethetỏ vissza (mint ahogy a Szílícium-völgy esetében történt), hanem arra, hogy Grenoble már az ipar fejlödése előtt is a vízienergia átalakítására épült elektrotechnikai körzet volt (és az is maradt). Mindemellett a regionális szakmai ágazat és a nemzeti közösség közötti feszültségek már a fordizmus hajnalán (amikor is az Alsthom magába szippantotta a Merlin-Guérin-t) felszínre kerültek Grenoble-ban.

A hálózatok körzetének sajátos atmoszférája azonban nem alakul ki egykönnyen. Toulouse-ban igazán csak a 1980-as években tapasztalhattunk valami hasonlót (a fejlett technológiával rendelkező iparágak Párizsból kiinduló, évtizedekig tartó voluntarista decentralizációja után), és annak ellenére, hogy egyes nyilatkozatok szerint Montpellier már "túlfejlettnek" tekinthető, mások szerint ez nem több "egy sivatagban felépült katedrálisnál".

Mondhatjuk, hogy itt a területi változások második dimenziójáról van szó: megjelenik a politikai, a közösségi reguláció. Mint ahogy azt már az elöbbiekben említettük, a politikai, közösségi reguláció színre lépését leginkább a "gouvernace" fogalmi kereti között tudjuk értelmezni. Foglaljuk össze tehát, hogy mit is értünk a vita politikai, közösségi dimenzióján: a közösségi reguláció (gouvernance) formájától, természetétől, erkölcsi vagy társadalmi vetületeitöl fưggetlenül tény, hogy a hálózatok létrejöttére és müködésére a közösségi reguláció a piaci folyamatokkal egyenértékủ (sőt, annál jelentősebb) hatást gyakorol. Ez a felismerés elegendö ahhoz, hogy megingassa a neoliberális modellek mindenhatóságába vetett hitet, és felhívja a figyelmet arra, hogy a termelöerök fejlödésében a piaci kapcsolatokon kívüli erők is szerepet játszanak.

Biztosak lehetünk abban, hogy azzal, hogy a közösségi, politikai reguláció során egyes fejlödési modelleket elönyben részesítenek másokkal szemben (a választott területfejlesztési akciók természetesen egy új társadalmi-területi egység megjelenésén alapulnak) meg is határozzák az ipari hálózat és a munkaeröpiac alapvető jellemzöit - egyszóval a területfejlesztés szempontjait is. Ez a megállapítás felveti a kérdést: milyen területi szinten értelmezhetjük ezeket a modelleket?

Egyesek "terület" alatt "országot" értenek, mivel szerintük a posztfordista forgatókönyvek lényegi, és a modellek közötti különbségeket megalapozó jellemzőit a bérarányok és a bérszintek eltéréseiben ragadhatjuk meg - és ezeket az eltéréseket leginkább a nemzeti szintủ jogszabályok és a szokásjog határozzák meg. Mások szerint azonban mindennek semmiféle gyakorlati - ső́t még elméleti - jelentősége sincs. Szerintük csak abban az esetben érdemes ezzel a megközelítéssel élnünk, ha a társadalmi-területi egységek rendelkeznek bizonyos szintü cselekvési szabadsággal, amely lehetővé teszi számukra, hogy bevezessenek egy, a nemzeti és nemzetközi politikai viszonyoktól (ie. az Európai Uniótól) ę a világgazdasági folyamatoktól független és a helyi sajátosságokat figyelembe vevö, újszerü közösségi regulációs gyakorlatot. 


\section{Összefoglalás}

A közösségi reguláció (gouvernance) különbözö formáit vizsgálva újra találkozunk a - társadalomtudományokban egylényegúként jelen lévő, esetünkben a lokális/globális fogalompár mentén megfogalmazódó - dialektika problematikájával. Ebben az értelemben csak akkor tipizálhatjuk a "nyertes" régiókat (pontosabban szólva, akkor tudjuk megfogalmazni, hogy milyen módszereket kell követni ahhoz, hogy egy régió sikeres legyen), ha nemzeti, vagy szövetségi állam-típusok szintjén közelítünk a dologhoz. A különbőző államok pedig akkor lesznek a világgazdasági verseny "nyertesei", ha megfelelö módon képesek ösztönözni és megalapozni ezen "nyertes régió"-típusok kialakulását és müködését.

Mondanunk sem kell, hogy itt gazdasági értelemben használjuk a "nyertes" szót. Nem kívánunk foglalkozni azzal, hogy milyen szempontok szerint nevezhetünk egy országot vagy régiót erkölcsi, politikai, társadalmi vagy ökológiai értelemben "gyöztesnek". Lehet, hogy ökológiai katasztrófával egyenlő az, ami ma Los Angeles-ben történik (ezzel egyébként Los Angeles vezetói is egyetértenének); a "picike" Frankfurtban azonban a Zöldeknek alig maradt mára tennivalójuk. Azt mondhatjuk, hogy Frankfurt egy feljövőben lévő gazdasági világhatalom pénzügyi központja, míg Los Angeles egy gazdasági bajokkal kủszködö "monstrum", az USA "nyertes" városa.

Kapcsoljuk össze tehát a minket régóta foglalkoztató kérdéseket (azaz a hálózatok és a politika kérdéskörét) a következö lényegbevágó problémával: "metropolisz" vagy "megapolisz"? Ezt a problémát a következőképpen is megfogalmazhatjuk. Eưópa "nyertes" részein található "sikeres" régiók (Dél-Németország és ÉszakOlaszország) "körzetek hálózataiba" rendeződnek, melyeket közepes méretü, metropolisz szintủ hálózatok körzetei egészítenek ki (mint például München, vagy Milánó). Los Angeles esetében azonban más a helyzet. Ott, sokkal inkább egy hatalmas, hálózatokat összefogó körzetet találunk, melyet gyakran annyira nehéz felismerni, hogy egyesek nem is hálózatok körzetéröl, hanem "hálózatok köreiröl" beszélnek. Hiszen milyen "atmoszféra" kötné is össze a régi Belváros kócerájait, ócska mühelyeit és Orange megye elektronikai iparát, hacsak nem az, hogy mindkettöben kizsákmányolt latin-amerikai emigránsok dolgoznak? Los Angeles hatalmas méreteit tekintve ezt a "körzetet" akár a "hálózatok szórt együttesének" is nevezhetnénk.

Engedjék meg, hogy végül egy kockázatos, és a tudomány mai állása szerint még nem bizonyítható megáłlapítással éljek. Ha igaz, hogy a fordizmus válságából való kilábalás két legfontosabb forgatókönyve szembeállítja egymással a "kevésbé szervezett" módon megvalósuló kapitalista változatot a "szervezettebb és az egyeztetési folyamatokra is hangsúlyt fekteto" megoldási módozatokkal; és ha igaz, hogy minél kisebb a közösségi reguláció (governance) explicit szerepe, a piacnak annál inkább támaszkodnia kell az agglomerálódás során implicit módon megnyilvánuló rendezö erőkre, akkor azt mondhatjuk, hogy az elsó forgatókönyv a "hálózatok szétszóródásának", míg a második a "körzetek hálózatainak" (kiegészülve néhány emberi léptékủ, hálózatokat magába foglaló körzettel) kialakulását segíti elő. Ha az első esetben létrejövő téregységeket "megapolisznak", míg a második esetben kialakuló hálózatok körzeteit "metropolisznak" nevezzük, 
akkor mondhatjuk, hogy a megapolisz a vesztes országokban található nyertes régiók (mint például, London vagy Los Angeles), míg a metropolisz (mint a hálózatok körzete és ebben a minöségében több, körzeteket összekötő hálózatnak a központja) a nyertes országokban található nyertes régiók térbeli megjelenési formája.

Fordította: Barta Györgyi és Králik Miklós

\section{Jegyzetek}

${ }^{1}$ Université de Paris I - Panthéon- Sorbonne, 191, Rue St-Jacques, 75005 Paris, France A szerző kőszonetét fejezi ki a kiváló fordításért, és a magyar változat kiadásának kezdeményezéséért.

${ }^{2}$ A francia Courlet, Pecqueur és a grenoble-i IREPD csoport koztes helyet foglal el

${ }^{3}$ angol kifejezés: A humán viselkedési formákat takarja. Szélesebb fogalom, mint a gouvernement = uralkodás, kormányzás. Az angolról franciára tơrténö forditás tehát igen problematikus. Talán a "reguláció" felel meg leginkább tartalmilag, de míg a „gouvernance” inkább a hatalmi és a piaci koordinációs kapcsolatok regulációjára vonatkozik, mi inkább a „Kőzosségi reguláció" használata mellett tesszuk le a voksot.

\section{Irodalom}

Amin A. (1989) Flexible specialisation and small firms in Italy: myths and realities, Antipode, 21, 13-34. o.

Amin A., Robins K. (1990a), The re-emergence of regional economies? The mythical geography of flexible accumulation, Environment and Planning D: Society and Space, 8, 7-34. o.

Amin A., Robins K. (1990b), Industrial districts and regional development: Limits and possibilities, in Pyke F., Becattini G., Sengenberger W., eds., Industrial Districts and Inter-firm Co-operation in Italy, Geneve, ILO, 185-219. o.

Aydalot P. (1984) A la recherche de nouveaux dynamismes spatiaux, in Aydalot P., ed., Crise et espace, Paris, Economica, 38-59. 0 .

Bagnasco A. (1977) Tre lialie. La problematica territoriale dello sviluppo economico italiano, Bologna, Il Mulino.

Bagnasco A., Trigilia C., (eds.) (1984) Societa e politica nelle aree di piccola impresa : il caso di Bassano, Venise, Arsenale

Bagnasco A., Trigilia C., $(1988,1993)$ La construction sociale du marché. Le défi de la troisieme Italie, Cachan, Ed. de l'ENS-Cachan

Bagnasco A., Trigilia C., (eds), (1988) Societa e politica nelle aree di piccola impresa : il caso della Valdelsa, Milan, Franco Angeli

Becattini G., ed., (1975) Lo Sviluppo economico della Toscana, Firenze, IRPET

Becattini G. (1979) Dal settore industriale al distretto industriale, Rivista di Economia e Politica Industriale, 5, 1, 7-21. 0 .

Becattini G. ed., (1987) Mercato e forze locali: il distretto industriale, Bologna, Il Mulino.

Becattini G., (1990) The Marshallian industrial district as a socio-economic notion, in Pyke F., Becattini G., Sengenberger W., eds., Industrial Districts and Inter-firm Co-operation in Italy, Geneve, ILO, 37-51.0.

Becatini G. (1991) Le district industriel: milieu créatif, Espaces et Sociétés, 66/67, 147-163. o.

Bellandi M. (1982) Il distretto industriale in Alfred Marshall,L'Industria, III, 3

Bellandi M. (1989) Small firms and industrial districts in Italy,Londres, Routledge.

Benko G. B. (1991) Géographie des technopôles, Paris, Masson 
Benko G. B. ed., (1990) La dynamique spatiale de l'économie contemporaine, La Garenne-Colombes, Editions de l'Espace Européen

Benko G. B. Dunford M., (eds), (1991) Industrial Change and Regional Development: the Transformation of New Industrial Spaces, London, Belhaven Press/Pinter

Benko G. B. Lipietz A. (eds.) (1992) Les régions qui gagnent. Districts et réseaux: les nouveaux paradigmes de la géographie économique, Paris, PUF

Braudel F. (1979) Civilisation matérielle, économie et capitalisme, Paris, A. Colin

Brusco S. (1982) The Emilian Model: Productive Decentralisation and Social Integration, Cambridge Journal of Economics, 6, 2, 167-184. o.

Brusco S. (1984) Quale politica industriale per i distretti industriali ?, Politica ed Economia, XV, 6, giugno

Brusco S. (1990) The idea of the industrial district: Its genesis, in Pyke F, Becattini G., Sengenberger W., eds., Industrial Districts and Inter-firm Co-operation in Italy, Geneve, ILO, 10-19. o.

Castells M., Godard F. (1974) Monopolville: l'entreprise, l'Etat, l'urbain, Paris, Mouton

Christaller W. (1933) Die zentralen Orte in Süddeutschland, Iéna, Fisher

Clark C. (1951a) The condition of economic progress, Londres, Macmillan

Clark C. (1951b) Urban population densities, Journal of the Royal Statistical Society, Serie A, 114, 490-496, o.

Claval P. (1989) L'avenir de la métropolisation, Annales de Géographie, 98, 692-706. o.

Coase R.H. (1937) The nature of the firm, Economica, 4, 16, 386-405. o.

Coriat B. (1991a) Penser a l'envers, Paris, C. Bourgois

Coriat B. (1991b) Technical flexibility and mass production: flexible specialisation and dynamic flexibility, in Benko G. B., Dunford M., eds., Industrial Change and Regional Development: the Transformation of New Industrial Spaces, London, Belhaven Press/Pinter, 134-158

Courlet C., Pecqueur B. (1989) Un modele de développement diffus en mutation: l'exemple du Choltais, Grenoble, Notes et Documents IREP-D, $n^{\circ} 29$

Courlet C., Pecqueur B. (1990) Systemes locaux d'entreprises et externalités: un essai de typologie, St Etienne, Communication au colloque «Mondialisation de l'économie et développement des territoires», 3-5 sept.

Courlet C., Pecqueur B., Soulage B. (1993) Industrie et dynamiques de territoires, Revue d'Economie Industrielle, 64, 7-21. 0 .

Fröbel F., Heinrichs J., Kreye O. (1980) The New International Division of Labor, Cambridge, Cambridge University Press

Ganne B. (1992) Industrial Development and Local Industrial Systems in Postwar France. Political Economy of a transformation, in Storper M., Scott A. J., eds,, Pathways to Industrialization and Regional Development, London, Routledge, 216-229. 0.

Garofoli G. (1985) Industrialisation diffuse en petite entreprise : le modele italien des années 70 Cahiers I.R.E.P.-développement, $\mathrm{n}^{\circ}$ 9, 245-256. o.

Garofoli G. (1986) Le développement périphérique en Italie, Economie et Humanisme, 289, 30-36. o.

Garofoli G. (1991) The Italian model of spatial development in the 1970s and 1980s, in Benko G. B., Dunford M., eds., Industrial Change and Regional Development: the Transformation of New Industrial Spaces, London, Belhaven Press/Pinter, 85-101. o.

Garofoli G. (1993) Economic development, organization of production and territory, Revue d'Economie Industrielle, 64, 22-37. o.

Harrison B. (1992) Industrial Districts: Old Wine in New Bottles ?, Reginal Studies, 26, 5, 469-483. o.

Hotelling H. (1929) Stability in Competition, Economic Journal, 39, 41-57. o.

Leborgne D., Lipietz A. (1991) Idées fausses et questions ouvertes de l'apres-fordisme, Espaces et Sociétés, 66/67, 39-68.0.

Leborgne D., Lipietz A. (1992) Conceptual Fallacies and Open Questions on Post-Fordism, in Storper M., Scott A. J., eds., Pathways to Industrialization and Regional Development, London, Routledge, 332-348, o.

Lipietz A. (1977) Le capital et son espace, Paris, Maspéro

Lipietz A. (1985) L'audace ou l'enlisement, Paris, La Découverte

Lipietz A. (1986) Industries et métropoles dans le tiers monde, Les Annales de la Recherche Urbaine, 29, 14-25. o.

Lipietz A. (1990a) La trame, la chaîne et la régulation: un outil pour les sciences sociales, Economies et Sociétés, Cahiers de l'ISMEA, Série R-5, 24, 12, 137-174. o. 
Lipietz A. (1990b) Le national et le régional: quelle autonomie face a la crise capitaliste mondiale?, in Benko G. B., ed., La dynamique spatiale de l'économie contemporaine, La Garenne-Colombes, Editions de l'Espace Européen, 71-103. o.

Lipietz A. (1993) Social Europe, legitimate Europe: the inner and outer boundaries of Europe, Environment and Planing D: Society and Space, 11, 5, 501-512. o.

Losch A. (1940) Die raümliche Ordnung der Wirtschaft, Iéna, Fisher

Marshall A. (1890) Principles of Economics, Londres, Macmillan

Marshall A. (1900) Elements of Economics of Industry, Londres, Macmillan

Marshall A. (1919) Industry and Trade, Londres, Macmillan

Martinelli F., Schoenberger E. (1992) Les oligopoles se portent bien, merci! Eléments de réflexion sur l'accumulation flexible, in Benko G. B., Lipietz A., eds., Les régions qui gagnent. Districts et réseaux: les nouveaux paradigmes de la géographie économique, Paris, PUF, 163-188. o.

Massey D. (1978) Regionalism: some current issues, Capital and Class, ${ }^{\circ} 6,106-125$. 0.

Massey D. (1984) Spatial Divisions of Labour, Londres, Macmillan

Massey D. (1985) New Directions in Space, in Gregory, D., Urry, J., Social Relations and Spatial Structures, Londres, Macmillan, 9-19. o.

Massey D., Meegan, R. (1982) The anatomy of job loss. The how, why and where of employment decline, Londres, Methuen

Pecqueur B. (1989) Le développement local, Paris, Syros

Piore M., Sabel C. (1984) The second Industrial Divide : possibilities for properity, New-York, Basic Books (Trad. française Les Chemins de la prospérité, Paris, Hachette, 1989)

Rostow W. (1963) Les étapes de la croissance économique, Paris, Seuil

Salais R. (1991) Flexibilité et conventions du travail: une approche, Economie Appliquée, 44, 2, 5-32. o.

Salais R., Storper M. (1993) Les mondes de production. Enquête sur l'identité économique de la France, Paris, Ed. de l'EHESS

Schoenberger E. (1988) From Fordism to flexible accumulation: technology, competitive strategies, and international location, Environment and Planing D: Society and Space, 6, 3, 245-262. o.

Scott A. J. (1988) Metropolis, From the Division of Labor to Urban Form, Los Angeles, University of California Press

Scott A. J. (1993) Technopolis. High-Technology Industry and Regional Development in Southern California, Berkeley,CA., University of California Press

Sforzi F. (1990) The quantitative importance of Marshallian industrial districts in the Italian economy, in Pyke F., Becattini G., Sengenberger W., eds., Industrial Districts and Inter-firm Cooperation in Italy, Geneve, ILO, 75-107. o.

Storper M., Harrison B. (1991) Flexibility, hierarchy and regional development: The changing structure of industrial production systems and their forms of governance in the 1990s, Research Policy, 20, 407-422. o.

Storper M., Walker R. (1989) The Capitalist Imperative. Territory, Technology and Industrial Growth, Oxford, Basil Blackwell

Vernon R. (1966) International investment and international trade in the product cycle, Quaterly Journal of Economics, 80, 190-207. o.

Wallerstein I. (1974) The Modern World System, New York, Academic Press

Williamson O. E. (1975) Markets and Hierarchies. Analysis and Antitrust Implications, New York, Free Press 